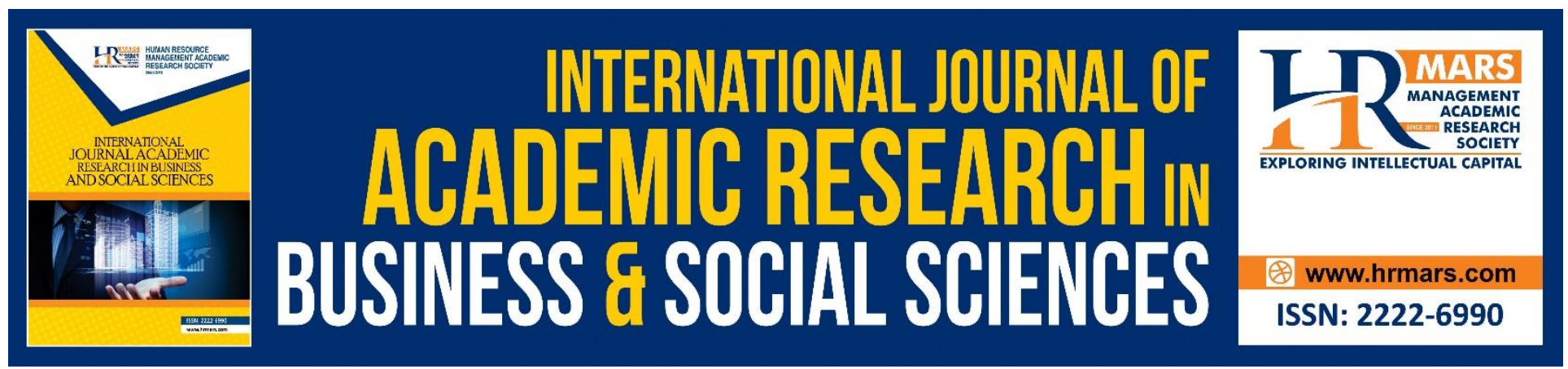

\title{
The Ethical Judgment to the Product-Harm Crisis: Evidence from Pakistan
}

\author{
Aasir llyas, Walied Askarzai
}

To Link this Article: http://dx.doi.org/10.6007/IJARBSS/v9-i6/6049

DOI: 10.6007/IJARBSS/v9-i6/6049

Received: 10 April 2019, Revised: 10 May 2019, Accepted: 10 June 2019

Published Online: 30 June 2019

In-Text Citation:(Ilyas \& Askarzai, 2019)

To Cite this Article: Ilyas, A., \& Askarzai, W. (2019). The Ethical Judgment to the Product-Harm Crisis: Evidence from Pakistan. International Journal of Academic Research in Business and Social Sciences, 9(6), $884-895$.

Copyright: (C) 2019 The Author(s)

Published by Human Resource Management Academic Research Society (www.hrmars.com)

This article is published under the Creative Commons Attribution (CC BY 4.0) license. Anyone may reproduce, distribute, translate and create derivative works of this article (for both commercial and non-commercial purposes), subject to full attribution to the original publication and authors. The full terms of this license may be seen

at: http://creativecommons.org/licences/by/4.0/legalcode

Vol. 9, No. 6, 2019, Pg. $884-895$

http://hrmars.com/index.php/pages/detail/IJARBSS

JOURNAL HOMEPAGE

Full Terms \& Conditions of access and use can be found at http://hrmars.com/index.php/pages/detail/publication-ethics 


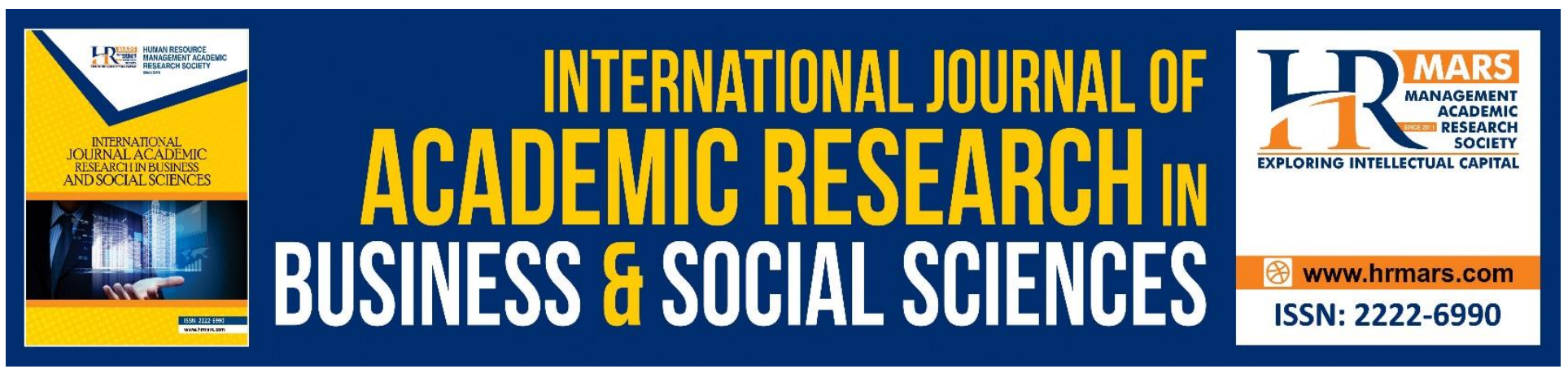

\title{
The Ethical Judgment to the Product-Harm Crisis: Evidence from Pakistan
}

\author{
Aasir llyas \\ Huazhong Agricultural University, Wuhan \\ Walied Askarzai \\ Academies Australasia Polytechnic \\ Email: aasirilyas@webmail.hzau.edu.cn,w.askarzai@aapoly.edu.au
}

\begin{abstract}
The study was conducted by evaluating the ethical judgment and product harm crises among the students in the public sector universities in Peshawar city-Pakistan. The study has taken the products of tetra pack juices in Peshawar i.e. Nestle, Maaza, etc. The study will be significant for the policymakers to control the market for especially to supply the quality product in the market. The issues related to the product harm crises sometimes lead to negative behavior shown by the consumers in the market towards the specific products. The study was conducted among the public sector universities and the students enrolled in these universities were taken as the population of the study. Based on stratified sampling (proportional allocation method) the study included 250 sample students for the data collection. The study has adopted a semi-structured closed-ended questionnaire for the questionnaire. The used regression model for data analysis. The findings of the reliability test used showed that the items included in the study data collection instrument have been found reliable and valid. The findings of the regression model showed that perceived crises severity has a significant effect on contempt while perceived crises relevance has insignificant; product knowledge has a significant moderating role between perceived crises severity, perceived crises relevance, and contempt. Perceived crisis relevance and perceived crises relevance have significant effects on anger; product knowledge has a significant moderating role between perceived crisis severity, perceived crises relevance, and anger. It has been recommended that the firms should keep a strong check and balance so that low-quality products might not enter into the market.
\end{abstract}

Keywords: Product Harm Crisis, Crisis Severity, Relevance, Anger, Contempt, Product Knowledge

\section{Introduction}

Crises are events that are difficult for a company to avoid. The types of crises are numerous, varying from 'small-scale organizational issues' to grave crises caused by external factors, such as earthquakes and fires, and may happen to any company at any time. A crisis can cause negative 
INTERNATIONAL JOURNAL OF ACADEMIC RESEARCH IN BUSINESS AND SOCIAL SCIENCES Vol. 9, No. 6, June, 2019, E-ISSN: 2222-6990 @ 2019 HRMARS

publicity, which in turn affects consumers' attitudes, beliefs, and future purchases. Therefore, managers should be effectively prepared to deal with crises. This preparation may include the development of a suitable communication strategy (Hale et al., 2005).

Product-harm crises, which are connected to defective or even dangerous products, are among the most common threats to a company. They can be defined as a sudden break in a product's life cycle, caused by problems such as the manufacturer's negligence or product misuse. Productharm crises could result in immense financial costs for a company. Product recalls are one of the possible ways a company can confront such crises (De-Matos and Rossi, 2007). However, despite the disturbing impact of product-harm crises, little systematic research has focused on consumer reactions or their marketing consequences.

As products are becoming increasingly complex, customers being more demanding and critical, product-related crises nowadays are even more frequent, global and hard to manage (Birch, 1994; Patterson, 1993). Moreover, such crises indicate importance to consumer or product user behavior which can significantly affect whether they will change their attitude or opinion towards a company and purchase its new product. Furthermore, product-related crises typically cost millions of dollars in the sales, market share, market value, and even stock price of the companies involved in the crises. Scholars in the area have spent decades of efforts in studying the effects and the potential consequence of product-harm crises, as well as various possible factors that can contribute to effective crisis management process.

The severity and high frequency of product-harm crisis prompted scholars to undertake a lot of research on its negative effects and coping strategies (Lin et al., 2011). For example, Ma et al. found that the product-harm crisis can negatively influence the customer's perceived value of the crisis brand (Ma et al., 2014). Lin et al., (2011) Found that the purchase intention is indirectly affected by corporate ability, negative publicity, and corporate social responsibility via the mediation of trust and effective identification purchase during the product-harm crisis.

Although some studies provided suggestions for companies to make effective responses to the product-harm crisis, the majority of them discussed consumers' reaction mechanism based on the selective information processing and crisis responsibility reasoning (Dawar et al., 2000; HassKotegger et al., 2013 \& Laufer and Coombs, 2006). There are still gaps in understanding the complex consumers' reactions (Klien and Dawar, 2004). For example, Kim used Expectancy Violations Theory to explain the impact of prior corporate associations on consumers' reaction to the product-harm crisis. These studies assumed that consumers have controlled cognition on a product-harm crisis, but they ignored the role of consumers' emotional intuition. Emotion can affect consumers' judgment, evaluation, and decision-making (Williams, 2014).

In recent years, a few scholars began to discuss the role of consumers' emotions in the product-harm crisis. For example, Kim and Cameron's experimental study revealed that anger and sadness could affect the consumers' emotional reaction to the product-harm crisis (Kim and Cameron, 2011). However, studies on emotional effects are still few. Also, the existing emotional studies examined consumers' reactions under the experimental conditions, instead of examining the reaction behavior in the real world (Bernad, 1985). Besides, according to the Attribution-AffectAction model, the judgment process is not only based on the individuals' rational reasoning, but also by the emotional effect and individual values (Bernad, 1985). Therefore, as a negative event occurs 
due to a controllable cause (Bernad, 1985), the research on the product-harm crisis needs to be based on a real case to carry out an investigation. In addition, the research on the product-harm crisis needs systematic examinations on the consumers' internal reaction. An integrated consumer response model is needed, including the consumers' emotional intuition and cognition processes on a productharm crisis. In fact, the consumers' reaction is a type of ethical judgments after the product-harm crisis. The product-harm crisis is an enterprises' basic ethical issue, which has an important ethical scene characteristic (Vassilkopoulou et al., 2011). Grappi et al (2013). thought that the harm to consumers can be regarded as a kind of ethical transgressions, which may damage the interests, freedom, and dignity of consumers (Grappi et al., 2013).

Needless to say, in the new global competitive economy, product-harm crises have become a central issue for almost every company. This is because any type of product-harm crises can have very real and sometimes unfortunate consequences that can put a company out of the competition. It is therefore practically important for companies to develop a realistic model of product-harm prevention. So far, however, there has been little discussion about the role of the product-harm crisis on companies' ethical actions. The objective of this research is to evaluate the role of product harm crisis (perceived crises severity, perceived crisis relevance) on ethical actions (Contempt, anger).

\section{Literature Review}

Past literature on product-harm crises has identified four factors that involve product harm and affect consumers' responses to company crisis situations: the company's reputation and social responsibility, the company's response to the crisis, the number and degree of injuries and the external effects during and after the crisis (Jolly and Mowen, 1985). Although there are other factors that may also affect consumer responses (for example, brand loyalty, pre-crisis category usage and advertising, attributions of responsibility and blame), the four above-mentioned factors (that is, the company's response, the company's social responsibility, the severity of crisis and the external effects) are the most important (Siomkos, 1989).

Chen, Ganesan, and Liu (2009) discovered whether a firm's product-recall strategy can affect its financial value, Lei, Dawar, and Gurhan-Canli (2012) assessed the relationship between base rate information and consumer attributions of product-harm crises, Vassilikopoulou et al., (2009) utilized conjoint analysis method to identify the factors that influence product-harm crisis management and ranked them by different crisis extent levels, Yannopoulu, Koronis, and Elliot (2011) revisited to what extent should media or public relations approaches be leveraged in building brand trust.

As indicated by Eilert et al., (2017), the company reviewed their failed products to limit mischief to target buyers and furthermore misfortune to the organization. Along these lines Eilert et al., (2017) in their examination research the impacts of product review on money markets and time for reviewing the affected product. Likewise, there investigate researched the directing part of brand attributes on the connection between an opportunity to review harm product and its impacts on a securities exchange. The vehicle industry in the vicinity of 1992 and 2012 were considered for gathering their information test of 381 recall cases. There came about uncovered that the connection between time to review a product and issue seriousness more grounded when the brand is different and the other way around. Along these lines, their investigation recommended that opportunity to review product under serious issue do impact administrator and approach producer choices. 
Erdem and Keane (1996) express that customers confront a specific level of vulnerability while assessing the quality and such vulnerability lessens with the expansion of the measure of data, achieving the shopper. Be that as it may, Zhao et al., (2011) are of another conclusion - when the data and signs are very surprising from the past ones, for example, in a crisis circumstance, the level of vulnerability develops altogether, and, in such case, the impression of value may essentially change amid a brief timeframe. These creators' examination demonstrates that emergencies negatively affect apparent product quality.

Product knowledge is a product related information stored in the consumer's memory, such as brands, products, features, evaluation, decision-making clues, and using methods, etc. (Ajzen and Fishbein, 1999; Marks and Olson, 1981). Product knowledge is an important moderating factor that affects the consumers' response to a product-harm crisis (Hass-Kotzeggar et al., 2013). Product knowledge includes the consumers' familiarity and expertise on the product. The familiarity is the consumers' accumulated product experience, including the cognitive structures (e.g., product features) and cognitive processes (e.g., decision rules based on the product features). The expertise refers to the consumers' ability to complete the related tasks of the product (Ahluwalia et al., 2000). Product knowledge can affect the consumers' emotional reaction in a product-harm crisis. By comparing with cognitive processing, the emotional intuition of consumers on the product-harm crisis is a fast and automatic reaction (Zajonc, 1980; Small et al., 2007).

In the product-harm crisis, consumers with rich product knowledge are more familiar with the product by comparing with the consumers who are a lack of product knowledge. Therefore, consumers with rich product knowledge are more likely to be involved in controlled cognitive processing on the evaluation of the crisis severity. Consumers with a high level of product knowledge will think that they can more easily judge the severity of the crisis, compared with consumers who have no related experiences. Controlled cognitive processing can weaken the consumers' emotional response to the crisis severity.

\section{Methodology}

The study was conducted in the Khyber Pakhtunkhwa market to evaluate the effect of product harm crisis on ethical and moral orientation among the students. The study was conducted on tetra packaging products available in Peshawar. All the tetra pack juices (Nestle, Maaza, etc) products were the population unit of the study.

Due to time and financial constraints it is not possible to include all students in the study therefore first of all as target population four public sector universities in Peshawar have been selected and then from these universities, further 250 units of analysis were selected through purposive sampling technique. The sample respondents were selected using a proportional allocation method (Cochran, 1977). For convenience, the proportional allocation method was used as:

$$
n_{i}=\frac{n}{N} \times N_{i}
$$

Where,

$n=$ the required sample size

$N=$ population size (total number of students)

$N_{i}=$ number of teaching personnel in the $\mathrm{i}^{\text {th }}$ university 
INTERNATIONAL JOURNAL OF ACADEMIC RESEARCH IN BUSINESS AND SOCIAL SCIENCES

Vol. 9, No. 6, June, 2019, E-ISSN: 2222-6990 @ 2019 HRMARS

$n_{i}=$ number of samples employees from $\mathrm{i}^{\text {th }}$ university

Table 3.1: Numbers of sampled students in the selected Universities.

\begin{tabular}{|l|l|l|}
\hline University & No. of students & Sampled students \\
\hline University of Peshawar & 424 & 93 \\
\hline Islamia College University & 143 & 31 \\
\hline The University of Agriculture & 293 & 64 \\
\hline IM Sciences & 276 & 61 \\
\hline Total & 1136 & 250 \\
\hline
\end{tabular}

Source: Registrar Offices \& Official Websites of universities

\section{Data Collection}

The data for the study was primary and was collected from different students of public sector universities working in Peshawar. The data of the variables was collected with the help of a closedended structured questionnaire. The questionnaire was based on multiple items and a five-point Likert scale. The questionnaire was administered personally.

\section{Variables}

\section{Independent Variables}

- Perceived Crises Severity

- Crises Relevance

\section{Dependent Variables}

- Contempt

- Anger

\section{Moderating Variable}

- Product Knowledge

\section{Hypotheses}

$\mathrm{H}_{1}$ : $\quad$ Perceived crises severity has a significant effect on contempt

$\mathrm{H}_{2}$ : $\quad$ Perceived crises severity has a significant effect on anger

$\mathrm{H}_{3}$ : $\quad$ Product knowledge has a significant moderating role between perceived crises severity and contempt

$\mathrm{H}_{4}$ : Product knowledge has a significant moderating role between perceived crises relevance and anger

$\mathrm{H}_{5}$ : Crises relevance severity has a significant effect on contempt

$\mathrm{H}_{6}$ : Crises relevance severity has a significant effect on anger

$\mathrm{H}_{7}$ : Product knowledge has a significant moderating role between perceived crises relevance and contempt

$\mathrm{H}_{8}$ : $\quad$ Product knowledge has a significant moderating role between perceived crises relevance and anger 
INTERNATIONAL JOURNAL OF ACADEMIC RESEARCH IN BUSINESS AND SOCIAL SCIENCES Vol. 9, No. 6, June, 2019, E-ISSN: 2222-6990 @ 2019 HRMARS

\section{Results \& Discussions}

\section{Demographic Distribution}

\begin{tabular}{cccc}
\hline \multirow{2}{*}{$\begin{array}{c}\text { Variable } \\
\text { Gender }\end{array}$} & Category & No of Participants & Percentage \\
& Male & 180 & 72 \\
\cline { 2 - 4 } & Female & 70 & 28 \\
\cline { 2 - 4 } Age & Up to 20 & 50 & 20 \\
& 21 to 24 & 160 & 64 \\
\cline { 2 - 4 } & Above 25 & 40 & 16 \\
\hline Marital Status & Married & 40 & 16 \\
& Unmarried & 210 & 84 \\
\hline
\end{tabular}

The table shows the findings for the demographic distribution of the sample respondents selected from the sample public sector universities based on their demographic features. The findings suggested that the male respondents are in majority with 72 percent as compared to female participants i.e. 28 percent. 64 percent of the respondents belongs to age from 21 to 24 and 84 percent of the respondents are unmarried.

\section{Reliability}

\begin{tabular}{|c|c|c|c|}
\hline Construct & Indicators & Standardized Loading & T-value \\
\hline \multirow[t]{5}{*}{ Perceived Crises Severity } & CS1 & 0.87 & 21.70 \\
\hline & CS2 & 0.89 & 36.19 \\
\hline & CS3 & 0.76 & 65.61 \\
\hline & CS4 & 0.71 & 20.19 \\
\hline & CS5 & 0.78 & 41.56 \\
\hline \multirow[t]{5}{*}{ Perceived Crises Relevance } & CR1 & 0.81 & 27.11 \\
\hline & CR2 & 0.76 & 44.53 \\
\hline & CR3 & 0.82 & 29.41 \\
\hline & CR4 & 0.91 & 33.31 \\
\hline & CR5 & 0.84 & 19.17 \\
\hline \multirow[t]{5}{*}{ Contempt } & $\mathrm{C} 1$ & 0.72 & 29.11 \\
\hline & $\mathrm{C} 2$ & 0.91 & 32.45 \\
\hline & $\mathrm{C} 3$ & 0.70 & 24.97 \\
\hline & C4 & 0.89 & 32.44 \\
\hline & $\mathrm{C} 5$ & 0.77 & 29.44 \\
\hline \multirow[t]{4}{*}{ Anger } & A1 & 0.79 & 31.27 \\
\hline & $\mathrm{A} 2$ & 0.88 & 84.99 \\
\hline & A3 & 0.87 & 65.12 \\
\hline & A4 & 0.80 & 49.40 \\
\hline \multirow[t]{5}{*}{ Product Knowledge } & P1 & 0.73 & 33.79 \\
\hline & $\mathrm{P} 2$ & 0.75 & 41.55 \\
\hline & P3 & 0.92 & 82.84 \\
\hline & $\mathrm{P} 4$ & 0.86 & 59.64 \\
\hline & P5 & 0.72 & 61.66 \\
\hline
\end{tabular}


INTERNATIONAL JOURNAL OF ACADEMIC RESEARCH IN BUSINESS AND SOCIAL SCIENCES Vol. 9, No. 6, June, 2019, E-ISSN: 2222-6990 @ 2019 HRMARS

The table shows the findings for the reliability and validity of the items used in the questionnaire for the data collection. The findings for the reliability found $<0.60$ which confirms the reliability and the $t$-value is also more than 2 which concludes the reliability of the items taken in the questionnaire.

\section{Product harm Crises and Contempt}

\begin{tabular}{|c|c|c|c|c|c|c|}
\hline \multirow{2}{*}{\multicolumn{2}{|c|}{ Model }} & \multicolumn{2}{|c|}{$\begin{array}{l}\text { Unstandardized } \\
\text { Coefficients }\end{array}$} & \multirow{2}{*}{$\begin{array}{c}\text { Standardized } \\
\text { Coefficients }\end{array}$} & \multirow[b]{2}{*}{$\mathrm{t}$} & \multirow[b]{2}{*}{ Sig. } \\
\hline & & B & Std. Error & & & \\
\hline \multirow[t]{3}{*}{1} & (Constant) & 1.749 & .198 & & 8.818 & .000 \\
\hline & Perceived Crises Severity & .501 & .051 & .535 & 9.831 & .000 \\
\hline & Crises Relevance & .050 & .056 & .049 & .894 & .372 \\
\hline
\end{tabular}

R: .559, R-square: .312, F-value: 67.43

The table shows the findings for the product harm crises and contempt among the students of public sector universities in Peshawar. The results suggested that perceived crises severity and crises relevance have a 55 percent relationship with contempt while they have 31 percent effects on the contempt as the R-square value suggested. The findings argued that perceived crises severity has a significant effect while crises relevance having insignificant effects on contempt. The dual-process theory stated that when the individual makes an ethical judgment, s/he may rely on intuitive emotional reaction (Greene, 2007). In the product-harm crisis, the corporate ethical transgression can induce the consumers' negative emotions, which will influence the consumers' ethical judgment directly. The emotion related to the interests of others or the whole society is called moral emotion. Moral emotion is a kind of emotional experience, which is based on the evaluation of other's behavior and thinking. For ethical transgression, individuals often produce other-condemning emotions, including contempt, anger, and disgust. In the product-harm crisis, the emotion induced by corporate harm behavior does not include disgust. In addition, people often confused with the differences between contempt and disgust emotion. Therefore, in this research, the impacts of contempt and anger are only considered on consumers' ethical judgment (Russell, 1991).

\section{Moderating}

\begin{tabular}{|rl|r|r|r|r|r|}
\hline \multirow{2}{*}{ Model } & \multicolumn{2}{|c|}{$\begin{array}{c}\text { Unstandardized } \\
\text { Coefficients }\end{array}$} & \multicolumn{2}{c|}{$\begin{array}{c}\text { Standardized } \\
\text { Coefficients }\end{array}$} & \\
\cline { 2 - 5 } & \multicolumn{1}{|c|}{$\mathrm{B}$} & Std. Error & \multicolumn{1}{c|}{ Beta } & \multicolumn{1}{c|}{$\mathrm{t}$} & \multicolumn{1}{c|}{ Sig. } \\
\hline 1 & (Constant) & 1.547 & .218 & & 7.098 & .000 \\
& Interaction1 & .607 & .060 & .604 & 10.084 & .000 \\
\hline
\end{tabular}

R: .604, R-square: .354, F-value: 101.695 
INTERNATIONAL JOURNAL OF ACADEMIC RESEARCH IN BUSINESS AND SOCIAL SCIENCES Vol. 9, No. 6, June, 2019, E-ISSN: 2222-6990 @ 2019 HRMARS

The table shows the moderating role of product knowledge along with perceived crises severity and crises relevance which shows the increase in the R or correlation coefficient, increase in $\mathrm{R}$-square and also increase can be seen in the beta value. These increases suggested that product knowledge has significant moderating between perceived crises severity and crises relevance and contempt.

\section{Product Harm Crises and Anger}

\begin{tabular}{|c|c|c|c|c|c|c|}
\hline \multirow{2}{*}{\multicolumn{2}{|c|}{ Model }} & \multicolumn{2}{|c|}{$\begin{array}{l}\text { Unstandardized } \\
\text { Coefficients }\end{array}$} & \multirow{2}{*}{$\begin{array}{c}\begin{array}{c}\text { Standardized } \\
\text { Coefficients }\end{array} \\
\text { Beta }\end{array}$} & \multirow[b]{2}{*}{$\mathrm{t}$} & \multirow[b]{2}{*}{ Sig. } \\
\hline & & B & Std. Error & & & \\
\hline \multirow[t]{3}{*}{1} & (Constant) & 1.158 & .234 & & 4.940 & .000 \\
\hline & Perceived Crises Severity & -.121 & .060 & -.105 & -2.007 & .046 \\
\hline & Crises Relevance & .826 & .066 & .649 & 12.453 & .000 \\
\hline
\end{tabular}

R: .607, R-square: .369, F-value: 86.70

The table shows the findings for the product harm crises and contempt among the students of public sector universities in Peshawar. The results suggested that perceived crises severity and crises relevance have a 60 percent relationship with contempt while they have 36 percent effects on the contempt as the R-square value suggested. The findings argued that perceived crisis severity and crisis relevance having significant effects on consumer anger. The experiences of contempt and anger can weaken the consumers' evaluation of the crisis brand. The product-harm crisis may happen when the corporation violates the market commitment (e.g., providing defective products), harms the consumers and violates the principle of fair exchange. Consumers will make negative word-of-mouth and other actions to punish the corporation (e.g., forcing the corporation to make a change) and show their contempt and anger in the product-harm crisis (e.g., maintaining the consumers' rights and market order). Therefore, contempt and anger can influence consumers' negative word of mouth. Furthermore, Grappi et al. (2013) also found that contempt, anger, and disgust can influence the consumers' negative word of mouth and protest in a corporate unethical behavior study (Grappi et al., 2013).

\section{Moderating}

\begin{tabular}{|c|c|c|c|c|c|c|}
\hline \multirow{2}{*}{\multicolumn{2}{|c|}{ Model }} & \multicolumn{2}{|c|}{$\begin{array}{c}\text { Unstandardized } \\
\text { Coefficients }\end{array}$} & \multirow{2}{*}{$\begin{array}{c}\text { Standardized } \\
\text { Coefficients }\end{array}$} & \multirow[b]{2}{*}{$\mathrm{t}$} & \multirow[b]{2}{*}{ Sig. } \\
\hline & & B & Std. Error & & & \\
\hline \multirow[t]{2}{*}{1} & (Constant) & 1.129 & .276 & & 4.095 & .000 \\
\hline & Interaction1 & .691 & .076 & .766 & 9.081 & .000 \\
\hline
\end{tabular}

R: .766, R-square: .617, F-value: 82.45 
INTERNATIONAL JOURNAL OF ACADEMIC RESEARCH IN BUSINESS AND SOCIAL SCIENCES Vol. 9, No. 6, June, 2019, E-ISSN: 2222-6990 @ 2019 HRMARS

The table shows the moderating role of product knowledge along with perceived crises severity and crises relevance which shows the increase in the R or correlation coefficient, increase in $\mathrm{R}$-square and increase can be seen in the beta value. These increases suggested that product knowledge has significant moderating between perceived crises severity and crises relevance and anger.

\section{Conclusion}

The product-harm crisis may happen when the corporation violates the market commitment (e.g., providing defective products), harms the consumers and violates the principle of fair exchange. Consumers will make negative word-of-mouth and other actions to punish the corporation (e.g., forcing the corporation to make a change) and show their contempt and anger in the product-harm crisis (e.g., maintaining the consumers' rights and market order). Therefore, contempt and anger can influence consumers' negative word of mouth. Moral emotion is a kind of emotional experience, which is based on the evaluation of other's behavior and thinking. For ethical transgression, individuals often produce other-condemning emotions, including contempt, anger, and disgust. In the product-harm crisis, the emotion induced by corporate harm behavior does not include disgust. In addition, people often confused with the differences between contempt and disgust emotion. Therefore, in this research, the impacts of contempt and anger are only considered on consumers' ethical judgment

\section{References}

Ahluwalia, R., Robert, E., Burnkrant, H., \& Rao, U. (2000). Consumer Response to Negative Publicity: The Moderating Role of Commitment. Retrieved from https://doi.org/10.1509\%2Fjmkr.37.2.203.18734

Ajzen, I., \& Fishbein, M. (1977). Attitude-behavior relations: A theoretical analysis and review of empirical research. Psychological Bulletin, 84(5), 888-918. Retrieved from http://dx.doi.org/10.1037/0033-2909.84.5.888

Chen, Y., Ganesan, S., \& Liu, Y. (2009). Does a Firm's Product Recall Strategy Affects Its Financial Value? An Examination of Strategic Alternatives During Product-Harm Crises Journal of Marketing. Retrieved from https://ssrn.com/abstract $=2655803$

Claeys, A., S., \& Cauberghe, V. (2014). What Makes Crisis Response Strategies Work? The Impact of Crisis Involvement and Message Framing. Retrieved from https://www.sciencedirect.com/science/article/abs/pii/S0148296312003050

Dawar, N., \& Pillutla, M. M. (2000). Impact of Product-Harm Crises on Brand Equity: The Moderating Role of Consumer Expectations. Retrieved from https://www.jstor.org/stable/1558501?seq=1\#metadata_info_tab_contents

Dutta, S., \& Pullig, C. (2011). Effectiveness of Corporate Responses to Brand Crisis: The Role of Crisis Type and Response Strategies. Retrieved from https://www.sciencedirect.com/science/article/abs/pii/S014829631100021X

Grappi, S., Romani, S., \& Bagozzi, R. P. (2013). Consumer Response to Corporate Irresponsible Behavior: Moral Emotions and Virtues. Retrieved from https://www.sciencedirect.com/science/article/abs/pii/S014829631300026X 
INTERNATIONAL JOURNAL OF ACADEMIC RESEARCH IN BUSINESS AND SOCIAL SCIENCES

Vol. 9, No. 6, June, 2019, E-ISSN: 2222-6990 @ 2019 HRMARS

Greene, J. D. (2007). The secret joke of Kant's soul. In Moral Psychology, The Neuroscience of Morality: Emotion, Disease, and Development. Retrieved from https://psycnet.apa.org/record/2007-14534-005

Haas-Kotzegger, U. and Schlegelmilch, B. (2013), "Conceptualizing consumers' experiences of product-harm crises", Journal of Consumer Marketing, Vol. 30 No. 2, pp. 112120. https://doi.org/10.1108/07363761311304924

Kim, S. (2014). What's worse in times of product-harm crisis? Negative corporate ability or negative CSR reputation? Retrieved from https://psycnet.apa.org/record/2013-26191-001

Kim, H. J., \& Cameron, G. T. (2011). Emotions Matter in Crisis: The Role of Anger and Sadness in the Publics' Response to Crisis News Framing and Corporate Crisis Response. Retrieved from https://journals.sagepub.com/doi/abs/10.1177/0093650210385813?journalCode=crxa

Klein, J., \& Dawar, N. (2004). Corporate social responsibility and consumers' attributions and brand evaluations in a product-harm crisis. Retrieved from https://www.sciencedirect.com/science/article/abs/pii/S0167811604000266

Laufer, D., \& Coombs, W. T. (2006). How should a company respond to a product harm crisis? The role of corporate reputation and consumer-based cues. Retrieved from https://www.sciencedirect.com/science/article/pii/S0007681306000188

Laufer, D., Gillespie, K., McBride, B., \& Gonzalez, S. (2005). The Role of Severity in Consumer Attributions of Blame: Defensive Attributions in Product-Harm Crisis in Mexico. Retrieved from https://www.tandfonline.com/doi/abs/10.1300/J046v17n02_03

Lin, C. P., Chen, S. C., Chiu, C. K., \& Lee, W. Y. (2011). Understanding Purchase Intention during Product-Harm Crisis: Moderating Effects of Perceived Corporate Ability and Corporate Social Responsibility. Retrieved from https://link.springer.com/article/10.1007/s10551-011-0824-y

Liu, Y., \& Shankar, V. (2015). The dynamic impact of product-harm crisis on brand preference and advertising effectiveness: An empirical analysis of the automobile industry. Retrieved from https://pubsonline.informs.org/doi/abs/10.1287/mnsc.2014.2095

Ma, B., Zhang, L., Wang, G., \& Li, F. (2014). The Impact of a Product-Harm Crisis on Customer Perceived Value. Retrieved from https://journals.sagepub.com/doi/10.2501/IJMR-2014023a.

Marks, L. J., \& Olson, J. C. (1981). Toward a Cognitive Structure Conceptualization of Product Familiarity. Retrieved from http://www.acrwebsite.org/search/view-conferenceproceedings.aspx? Id=9800.

Mitroff, I. I. (2004). Crisis Leadership: Planning for the Unthinkable; John Wiley \& Sons: New York, NY, USA.

Small, D. A., Loewenstein, G., \& Slovic, P. (2007). Sympathy and Callousness: The Impact of Deliberative Thought on Donations to Identifiable and Statistical Victims. Retrieved from https://www.sciencedirect.com/science/article/pii/S0749597806000057

Small, D. A., \& Verrochi, N. M. (2009). The Face of Need: Facial Emotion Expression on Charity Advertisements. Retrieved from https://journals.sagepub.com/doi/abs/10.1509/jmkr.46.6.777_JMR6F 
Van Heerde, H., Helsen, K., \& Dekimpe, M. G. (2007) The Impact of a product-harm crisis on marketing effectiveness. Retrieved from https://pubsonline.informs.org/doi/abs/10.1287/mksc.1060.0227

Vassilikopoulou, A., Chatzipanagiotou, K., Siomkos, G., \& Triantafillidou, A. (2011). The Role of Consumer Ethical Beliefs in Product-Harm Crises. Retrieved from https://onlinelibrary.wiley.com/doi/abs/10.1002/cb.348

Weiner, B. (1985). An attributional theory of achievement motivation and emotion. Psychological Review, 92(4), 548-573. Retrieved from http://dx.doi.org/10.1037/0033-295X.92.4.548

Williams, P. (2014). Emotions and Consumer Behavior. Retrieved from https://academic.oup.com/jcr/pages/emotions_and_consumer_behavior

Zajonc, R. B. (1980). Feeling and Thinking: Preferences Need No Inferences. Retrieved from https://psycnet.apa.org/record/1980-09733-001 